\title{
Synthesis of new indole benzylic alcohols as potential precursors of calixindoles
}

\author{
David StC Black,* Naresh Kumar, and Tutik Dwi Wahyuningsih \\ School of Chemistry, The University of New South Wales, UNSW Sydney, NSW 2052, Australia \\ E-mail: d.black@unsw.edu.au
}

Dedicated to Professor Torbjörn Norin on the occasion of his 75th birthday

\begin{abstract}
3-(4-Chlorophenyl)-4,6-dimethoxyindole 8 was converted into the 7- and 2- substituted glyoxylamide derivatives 11 and 12, which were in turn reduced by sodium borohydride to the corresponding benzylic alcohols 13 and 14. Indole 8 was also acylated via a Houben-Hoesch reaction, with benzyl cyanides to give the 7-substituted methylene ketones 16a-c, which were also reduced by sodium borohydride to the corresponding benzylic alcohols 17a-c. All the benzylic alcohols were subjected to a variety of acidic conditions, but failed to generate calixindoles.
\end{abstract}

Keywords: Indoles, glyoxamides, benzyl cyanides, benzylic alcohols, Houben-Hoesch acylation, calixindoles

\section{Introduction}

Calix[3]indoles have been synthesised from activated 3-substituted-4,6-dimethoxyindoles with the three indole rings linked by carbon bridges through the C2 and C7 positions. ${ }^{1-4}$ These compounds can be achieved in two ways. One is the reaction of the indole with an aryl aldehyde in the presence of phosphoryl chloride. The other involves the acid catalysed reaction of an indole hydroxymethyl compound, which could be derived from the related formyl indole by sodium borohydride reduction. In general the flattened partial cone conformer was found to be preferred over the cone conformer, but the cone conformer could be stabilised to some extent by the use of amido substituents on the linking methine carbon atoms. ${ }^{5}$ Thus, the 7 - and 2 - indolyl hydroxyethanamides $\mathbf{1}$ and $\mathbf{2}$ respectively were converted into a mixture of the flattened partial cone calix[3]indole $\mathbf{3}$ and the cone calix[3]indole $\mathbf{4}$ (Scheme 1). In the cone conformer $\mathbf{4}$, the carbonyl oxygen atom of the amide substituent is hydrogen bonded to the adjacent indole $\mathrm{NH}$ 
atom and thus provides some conformational stability. However, in all cases the flattened partial cone conformer $\mathbf{3}$ was the major product and the cone conformer $\mathbf{4}$ was the minor one.

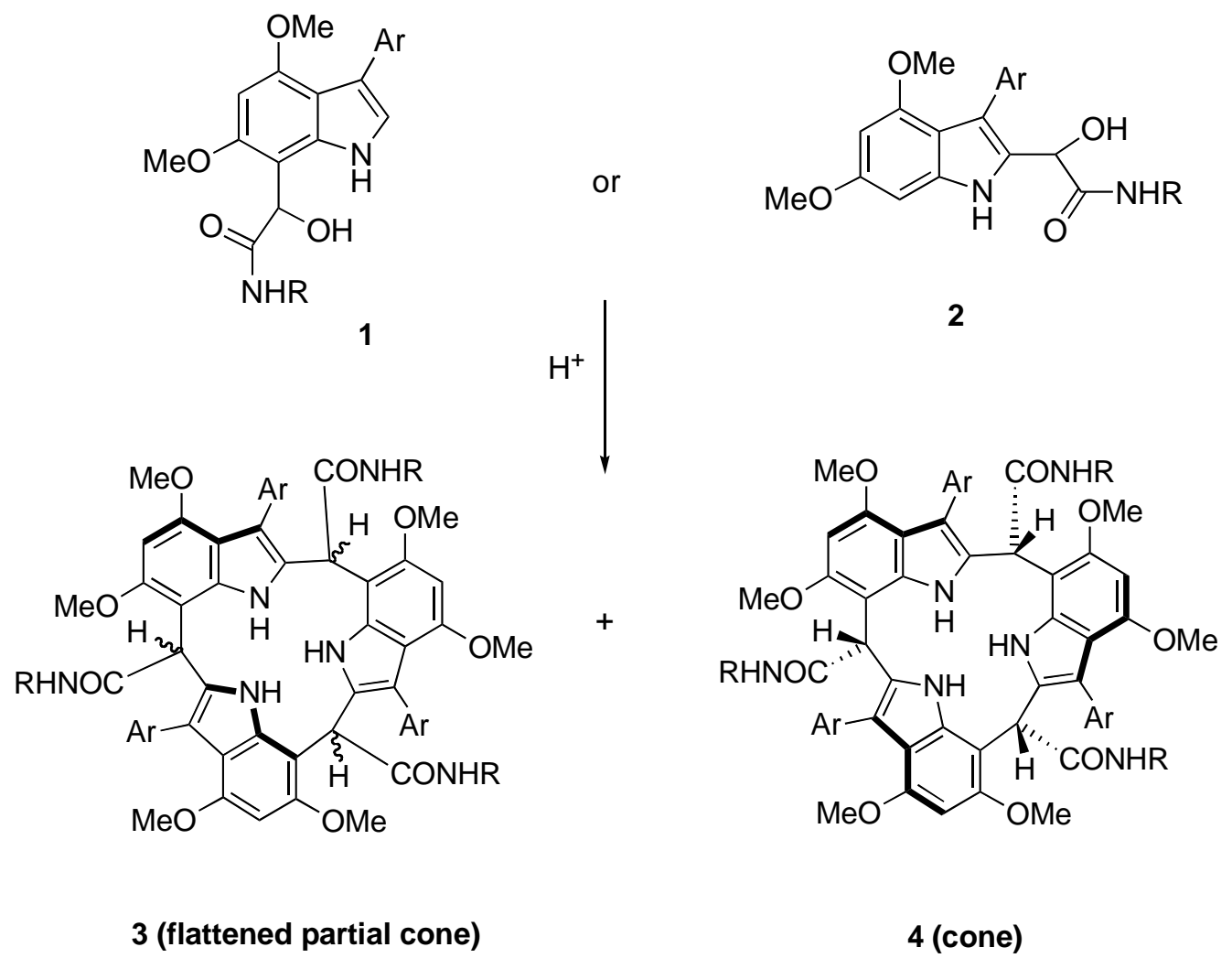

\section{Scheme 1}

In order to stabilize and maximize the cone conformation, the macrocyclic system could possibly be capped either at the top or the bottom rim. For example, the upper rim of calixarenes has been capped by the use of polymethylene bridges $^{6-9}$ while methylene, polymethylene, silyl and diazanaphthalene bridges have also been used for calixresorcinarenes. ${ }^{10-11}$ These caps have usually been introduced after calixarene formation.

In the case of calixindoles the cap must be generated from a tethered indole precursor, making use of the C3 indole substituents or substituents on the linking methine carbon atoms. In connection with the first approach, the tris-indole methanol 7 was previously prepared for this purpose from the tris-indole 5 , via the tris-indole aldehyde $\mathbf{6} .^{12}$ However, reaction of tris-indole 5 with $p$-chlorobenzaldehyde and phosphoryl chloride in chloroform or with formaldehyde in acetic acid gave only polymeric material. Furthermore, acid treatment of the tris-indole methanol 7 also failed to give the desired calix[3]indole. This failure presumably is caused by the nonideal length of the tether. Consideration of more flexible and variable tethers led to the investigation of the use of tris (2-aminoethyl)amine as a linker. This paper describes two preliminary approaches, both aimed at employing a substituent on the linking carbon atom. 


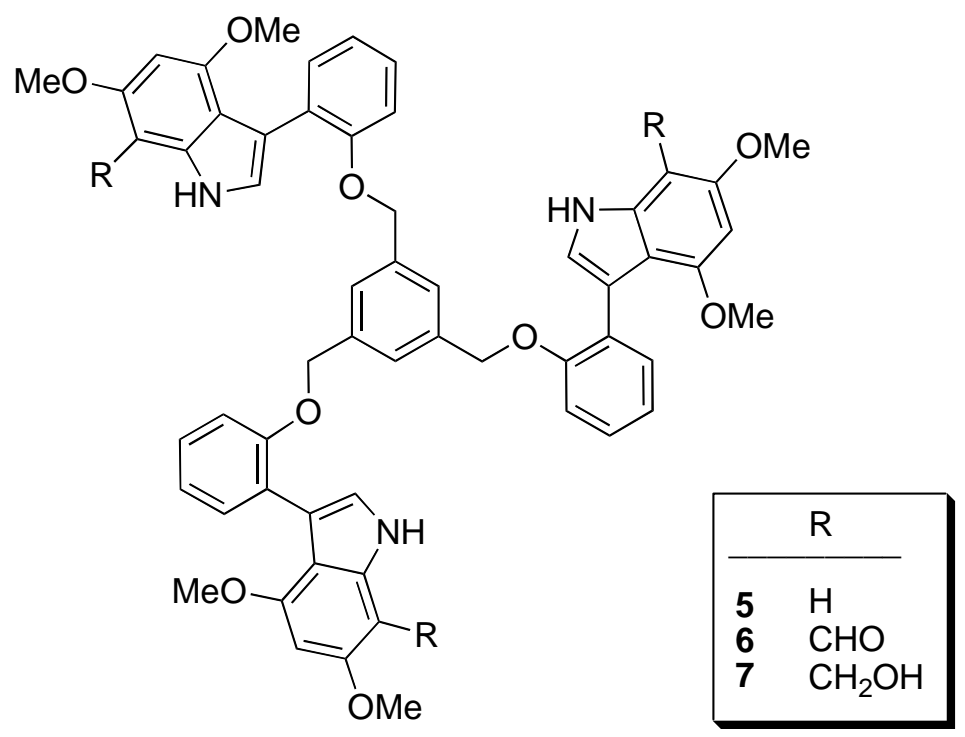

\section{Results and Discussion}

It has been shown previously that 3-aryl-4,6-dimethoxyindoles, such as 3-(4-chlorophenyl)-4,6dimethoxyindole 8, could react with oxalyl chloride to give 7- and 2-glyoxylic acid chlorides, such as compounds $\mathbf{9}$ and $\mathbf{1 0}$ respectively. The acid chlorides then react with various amines to produce the related glyoxylamides. ${ }^{12}$ A similar reaction using a one-third equivalent of tris (2aminoethyl)amine with glyoxylic acid chloride $\mathbf{9}$ afforded the tris-indolylglyoxylamide $\mathbf{1 1}$ in $67 \%$ yield (Scheme 2). The ${ }^{1} \mathrm{H}$ NMR spectrum clearly showed the presence of two broad peaks at 2.79 and $3.51 \mathrm{ppm}$ for methylene protons and a triplet at $8.31 \mathrm{ppm}$ for the amide protons indicating that the tris (2-aminoethyl)amine has been linked to the indole-glyoxylic function and with one set of signals also reflecting the three-fold axis of symmetry. The tris indolyl compound 11 was then reduced with sodium borohydride in methanol and yielded a single diastereomer of the desired alcohol $\mathbf{1 3}$ as a white solid (Scheme 2). The mass spectrum of this compound revealed a molecular ion at $\mathrm{m} / \mathrm{z} 1177\left({ }^{35} \mathrm{Cl}, 100 \%\right)$, whereas the ${ }^{13} \mathrm{C}$ NMR spectrum clearly showed the presence of a methine carbon resonating at $66.8 \mathrm{ppm}$. The ${ }^{1} \mathrm{H}$ NMR spectrum in $d_{6}{ }^{-}$ DMSO displayed two doublets at 5.52 and 5.93 ppm with a coupling constant of $4.1 \mathrm{~Hz}$ corresponding to the methine and hydroxyl protons respectively and it was also observed that the nitrogen proton resonance was shifted downfield to $10.54 \mathrm{ppm}$. Attempts to join the three indoles were made by treatment of the tris-hydroxyethanamide $\mathbf{1 3}$ with concentrated hydrochloric acid. However, the ${ }^{1} \mathrm{H}$ NMR spectrum of the crude product showed no evidence of a macrocyclic compound, and the broadened signals indicated a polymeric material.

It has been shown previously that the 2-substituted hydroxyethanamides gave higher yields of calix[3]indoles than the 7-substituted isomers. ${ }^{5}$ Treatment of the 2-glyoxylic acid chloride 10 with a one-third equivalent of tris (2-aminoethyl)amine in dichloromethane at room temperature for 1 hour gave the tris indol-2'-yl glyoxylamide 12 in 45\% yield (Scheme 2). 
<smiles>COc1cc(OC)c2c([Al])c[nH]c2c1</smiles>

8 $\mathrm{Ar}=4-\mathrm{ClC}_{6} \mathrm{H}_{4}$<smiles>COc1cc(OC)c2c(C(=O)C(=O)NCCN(CCNC(=O)C(=O)c3c(OC)cc([Al])c4c([Al])c[nH]c34)CCNC(=O)C(=O)c3c(OC)cc(OC)c4c([Al])c[nH]c34)c[nH]c2c1OC</smiles><smiles></smiles>
13<smiles>COc1cc(OC)c2c(Br)c[nH]c2c1C(=O)C(=O)Cl</smiles><smiles></smiles>

10<smiles>COc1cc(OC)c2c([Al])c(C(=O)C(=O)NCCN(CCNC(C)=O)CCNC(=O)C(=O)c3[nH]c4cc(OC)cc(OC)c4c3[Al])[nH]c2c1</smiles><smiles>COc1cc(OC)c2c([Al])c(C(=O)C(N)=O)[nH]c2c1</smiles>

12 $\mathrm{NaBH}_{4}$<smiles>COc1cc(OC)c2c([Al])c(C(O)C(=O)NCCN(CCNC(=O)C(O)c3[nH]c4cc(OC)cc(OC)c4c3[Al])CCNC(=O)C(O)c3[nH]c4cc(OC)cc(OC)c4c3[Al])[nH]c2c1</smiles>

\section{Scheme 2}


The mass spectrum clearly showed the molecular ion at $m / z 1171\left({ }^{35} \mathrm{Cl}, 2 \%\right)$ and the ${ }^{1} \mathrm{H}$ NMR spectrum exhibited the same pattern as glyoxylamide $\mathbf{1 1}$ with the proton nitrogen shifted downfield at $11.21 \mathrm{ppm}$ indicating a greater degree of hydrogen bonding. The glyoxylamide 12 also readily underwent reduction with excess sodium borohydride in methanol to give a single diastereomer of the related alcohol 14 in 89\% yield (Scheme 2). Unfortunately, acid treatment of alcohol $\mathbf{1 4}$ with hydrochloric acid in tetrahydrofuran also failed to give the calix[3]indole, and again gave polymer.

Numerous acid catalysts have been shown to be effective for calixindole formation. ${ }^{2}$ However these other conditions also led to polymeric products. It is highly likely that the problem of calixindole formation lies with the geometry of the tether rather than the acid catalyst. Thus an alternative approach to tether formation was explored.

Most calix[3]indoles so far prepared have an aryl substituent directly attached to the carbon centre of the bridge linking the $\mathrm{C} 2$ and $\mathrm{C} 7$ positions. This provides a limited scope for substitution and subsequent linkage of the substituent functions on the three aryl groups. A potentially more useful substituent on the C2 - C7 methine link could be an aryl acetyl moiety, which could possibly be linked through the carbonyl groups. Therefore, it was of interest to synthesise some aryl acetyl indoles as potential precursors of calix[3]indoles.

Friedel-Crafts acylation with nitriles in the presence of acid (hydrochloric acid and /or a Lewis acid) is well known as the Houben-Hoesch reaction. The first step is thought to involve protonation of a nitrile compound to give a nitrilium ion or nitrile-Lewis acid complex, which is regarded as the electrophilic species.

When the indole 8 was treated with benzyl cyanides 15a-c under Houben-Hoesch conditions a modest yield of the corresponding benzylketones 16a-c resulted (Scheme 3). Although the reaction is easy to perform, it takes three days for completion, as the reaction mixture needs to be saturated twice with hydrogen chloride gas, then acidified with $2 \%$ aqueous hydrochloric acid, and finally heated under reflux for 3 hours. Moreover, in these examples, it was always observed that the crude solid product was poorly soluble in most organic solvents and difficult to characterize.

Clear evidence for benzylketones 16a-c was given by the mass spectra showing molecular ions at $\mathrm{m} / \mathrm{z} 407\left(\mathrm{M}+1,{ }^{35} \mathrm{Cl}, 100 \%\right), 422\left(\mathrm{M},{ }^{35} \mathrm{Cl}, 100\right)$ and $437\left(\mathrm{M}+1,{ }^{35} \mathrm{Cl}, 100\right)$ respectively. The ${ }^{1} \mathrm{H}$ NMR spectra indicated the presence of methylene proton resonances in the range of 4.33$4.42 \mathrm{ppm}$. In confirmation, the ${ }^{13} \mathrm{C}$ NMR spectra showed the presence of two signals in the range of 49.8-50.8 ppm and 198.6 ppm corresponding to methylene and carbonyl carbons respectively. Again, reduction of benzylketones 16a-c with excess sodium borohydride under similar conditions gave the alcohols 17a-c in high yield (Scheme 3 ). The ${ }^{1} \mathrm{H}$ NMR spectra of alcohols $17 \mathrm{a}-\mathrm{c}$ showed two multiplets in the range of 2.74-3.10 ppm corresponding to the methylene protons and another multiplet in the range of 5.28-6.37 ppm indicating the methine and hydroxyl protons. 
<smiles>COc1cc(OC)c2c([AlH])c[nH]c2c1</smiles>

8

$\mathrm{Ar}=4-\mathrm{ClC}_{6} \mathrm{H}_{4}$

\begin{tabular}{|ll|}
\hline $\mathbf{1 5}-\mathbf{1 7}$ & $\mathrm{R}$ \\
\hline $\mathbf{a}$ & $\mathrm{H}$ \\
$\mathbf{b}$ & $\mathrm{OH}$ \\
$\mathbf{c}$ & $\mathrm{OMe}$ \\
\hline
\end{tabular}

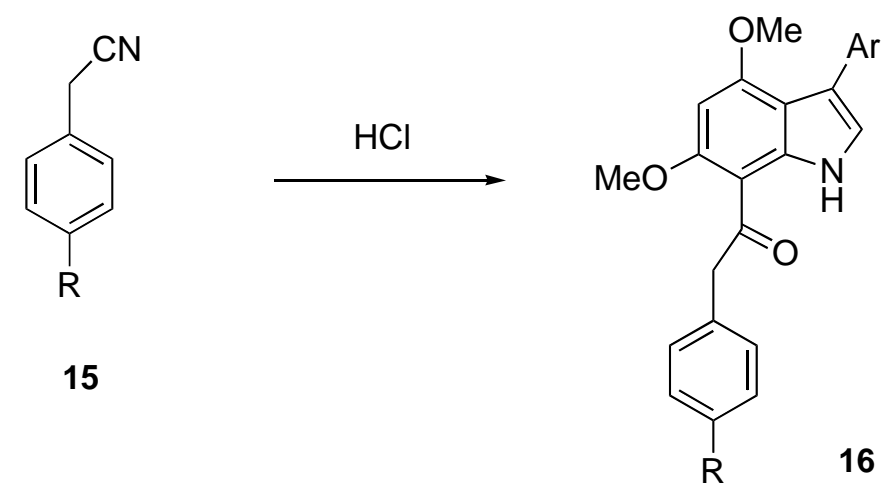<smiles>[R]c1ccc(CC(O)c2c(OC)cc(OC)c3c([Al])c[nH]c23)cc1</smiles>

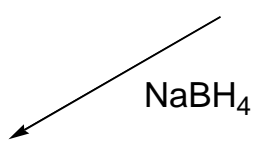

$\mathrm{NaBH}_{4}$

\section{Scheme 3}

Treatment of the alcohols 17a-c with hydrochloric acid in tetrahydrofuran gave only complex product mixtures. A variety of alternative acid catalysed reactions so far have shown no better outcomes, and no calixindoles have been isolated. The reason for the lack of calixindole formation is not clear, but a possible competing dehydration process could be responsible. However, the possible stilbene products were not detected nor isolated from the complex reaction mixtures.

The reactions described here, although failing to yield new examples of calixindoles, do however help to define the scope and limitations of calixindole formation.

\section{Experimental Section}

General Procedures. Melting points were determined on a Mel-Temp melting point apparatus and are uncorrected. Elemental analyses were performed by the Campbell Microanalytical Laboratory, University of Otago, New Zealand. Infrared spectra were obtained on a Mattson Genesis series FTIR spectrometer. Ultraviolet spectra were measured on Carey 100 spectrophotometers. ${ }^{1} \mathrm{H}$ NMR spectra were recorded at $300 \mathrm{MHz}$ with a Bruker AC300F or at $500 \mathrm{MHz}$ with a Bruker AM500 spectrometer and refer to deuterochloroform solutions with chloroform $(7.26 \mathrm{ppm})$ as an internal standard or to dimethyl- $\mathrm{d}_{6}$-sulfoxide solution with 
dimethylsulfoxide as an internal standard (2.50 ppm). Chemical shifts $(\delta)$ are in ppm relative to internal tetramethylsilane. ${ }^{13} \mathrm{C}$ NMR spectra were recorded in the designated solvents on a Bruker AC300F (75.50 MHz) and chemical shifts are reported in ppm downfield from TMS and identifiable carbons are given. The EI mass spectra were measured using a VG Quattro mass spectrometer at $70 \mathrm{eV}$ ionization voltage and $200^{\circ} \mathrm{C}$ ion source temperature. The principle ion peaks $m / z$ are reported together with their percentage intensities relative to the base peak. Dry chromatography was carried out using Merck 60H silica gel and refers to the technique of applying suction at the base of the column. Column chromatography was performed using Merck 60 Silica Gel whilst preparative thin layer chromatography was performed on 20x20x0.1 cm plates using Merck silica gel 7730 60GF 254 . Compounds were detected by short and long wavelength ultraviolet light.

Tris-2-(3-(4-chlorophenyl)-4,6-dimethoxyindol-7-glyoxylamidoethyl)amine (11). Indole 9 (0.50 g, $1.32 \mathrm{mmol}$ ) was dissolved in anhydrous dichloromethane (25 mL) and tris-(2aminoethyl)amine $(0.075 \mathrm{~mL}, 0.50 \mathrm{mmol})$ was added. The mixture was stirred at room temperature for $1 \mathrm{~h}$, water was added and the organic layer was separated, washed with water, dried and concentrated. The residue was chromatographed with dichloromethane/methanol (95:5) to give the title compound $11(0.41 \mathrm{~g}, 67 \%)$ as a yellow solid, mp $170-172^{\circ} \mathrm{C}$. Anal. Calcd. $\mathrm{C}_{60} \mathrm{H}_{54} \mathrm{Cl}_{3} \mathrm{~N}_{7} \mathrm{O}_{12}$ 0.8 $\mathrm{H}_{2} \mathrm{O}$ : C, 60.8; H, 4.7; N, 8.3. Found: C, 60.7; H, 4.7; N, 8.2. IR ( $\left.\mathrm{KBr} \mathrm{cm}^{-1}\right)$ 3403, 3311, 1664, 1581, 1536, 1464, 1356, 1322, 1215, 1179, 1088, 979. UV (MeOH nm, $\left(\mathrm{cm}^{-}\right.$ $\left.\left.{ }^{1} \mathrm{M}^{-1}\right)\right) 204$ (89,950), 255 (51,000), 335 (27,950). ${ }^{1} \mathrm{H}$ NMR (300 MHz, CDCl $) \delta 2.79$ (6H, bs, $\mathrm{NCH}_{2}$ ), 3.51 (6H, bs, $\left.\mathrm{NHCH}_{2}\right), 3.93,3.96$ (18H, 2s, OMe), 5.83 (3H, s, H5), 6.21 (3H, s, H2), 7.10 (6H, bs, ArH), 8.31 (3H, bs, CONH), 9.11 (3H, bs, NH). ${ }^{13} \mathrm{C}$ NMR $\left(75 \mathrm{MHz}, \mathrm{CDCl}_{3}\right) \delta 36.2$ $\left(\mathrm{CH}_{2}\right)$, $50.3\left(\mathrm{CH}_{2}\right)$, 55.5, 57.1 (OMe), 87.8 (C5), 122.3 (C2), 127.8, 130.1 (ArCH), 100.5, 109.7, 117.1, 131.9, 132.8, 138.2, 161.9, 162.9 (ArC), 168.7, 190.8 (CO). Mass spectrum (ES) : m/z 1170 (M-1, $\left.{ }^{35} \mathrm{Cl}, 100 \%\right)$.

Tris-2-((3-(4-chlorophenyl)-4,6-dimethoxyindol-7-yl)-2-hydroxyethanamido-ethyl)amine (13). Indole 11 (0.20 g, $0.17 \mathrm{mmol})$ was dissolved in methanol (20 mL) to which excess sodium borohydride was added, and the mixture was heated under reflux for $1 \mathrm{~h}$. Water was added and the resulting precipitate was filtered, washed with water and dried to yield the title compound 13 (0.16 g, 83\%) as a white solid, mp $204^{\circ} \mathrm{C}$ (dec). Anal. Calcd. $\mathrm{C}_{60} \mathrm{H}_{60} \mathrm{Cl}_{3} \mathrm{~N}_{7} \mathrm{O}_{12} .0 .6 \mathrm{H}_{2} \mathrm{O}: \mathrm{C}, 60.6$; H, 5.2; N, 8.3. Found: C, 60.3; H, 5.0; N, 8.2. IR $\left(\mathrm{KBr} \mathrm{cm}^{-1}\right)$ 3381, 1656, 1594, 1539, 1333, 1211, 1088. UV (MeOH nm, $\left.\left(\mathrm{cm}^{-1} \mathrm{M}^{-1}\right)\right) 202$ (75,600), 222 (68,700), 270 (32,800). ${ }^{1} \mathrm{H}$ NMR (300 MHz, d $\left.\mathrm{d}_{6}-\mathrm{DMSO}\right) \delta 2.58$ (6H, bs, $\left.\mathrm{NCH}_{2}\right), 3.19$ (6H, bs, $\left.\mathrm{NHCH}_{2}\right), 3.74,3.78(18 \mathrm{H}, 2 \mathrm{~s}, \mathrm{OMe}), 5.52$ (3H, d, $J=4.1 \mathrm{~Hz}, \mathrm{CH}), 5.93$ (3H, d, $J=4.1 \mathrm{~Hz}, \mathrm{OH}), 6.37$ (3H, s, H5), 7.12-7.14 (3H, m, H2), $7.31(6 \mathrm{H}, 2 \mathrm{~d}, J=7.9 \mathrm{~Hz}, \mathrm{ArH}), 7.48$ (6H, 2d, $J=8.3 \mathrm{~Hz}, \mathrm{ArH}), 7.94$ (3H, bs, CONH), 10.54 (3H, bs, NH). ${ }^{13} \mathrm{C}$ NMR (75 MHz, d 6 -DMSO) $\delta 37.0\left(\mathrm{CH}_{2}\right), 53.4\left(\mathrm{CH}_{2}\right), 55.5,57.9(\mathrm{OMe}), 66.8$ (CH), 90.3 (C5), 123.2 (C2), 127.7, 130.9 (ArCH), 106.1, 110.7, 115.6, 130.1, 135.5, 136.9, 153.8, 153.9 (ArC), 172.5 (CO). MS (ES) m/z: 1177 (M, $\left.{ }^{35} \mathrm{Cl}, 100 \%\right)$. 
Tris-2-(3-(4-chlorophenyl)-4,6-dimethoxyindol-2-glyoxylamidoethyl)amine (12). This was prepared as described for indole 11 from indole 10 (0.50 g, $1.33 \mathrm{mmol})$ and tris-(2-aminoethyl) amine $(0.075 \mathrm{~mL}, 0.49 \mathrm{mmol})$ in dichloromethane $(10 \mathrm{~mL})$ to give the title compound $12(0.57 \mathrm{~g}$, $45 \%$ ) as an orange solid, mp $154-156^{\circ} \mathrm{C}$. Anal. Calcd. $\mathrm{C}_{60} \mathrm{H}_{54} \mathrm{Cl}_{3} \mathrm{~N}_{7} \mathrm{O}_{12} 0.4 \mathrm{H}_{2} \mathrm{O}$ : C, 61.1; H, 4.7; N, 8.3. Found: C, 61.0; H, 4.5; N, 8.3. IR $\left(\mathrm{KBr} \mathrm{cm}^{-1}\right)$ 3340, 1620, 1510, 1479, 1207, 1154, 1131, 1087, 811. UV (MeOH nm, $\left.\left(\mathrm{cm}^{-1} \mathrm{M}^{-1}\right)\right) 210$ (104,950), 260 (50,750), 348 (42,300). ${ }^{1} \mathrm{H}$ NMR (300 $\left.\mathrm{MHz} \mathrm{CDCl}_{3}\right) \delta 2.69$ (6H, bs, $\left.\mathrm{NCH}_{2}\right), 3.33$ (6H, bs, $\left.\mathrm{NHCH}_{2}\right)$, 3.58, 3.76 (18H, 2s, OMe), 5.99 (3H, s, H5), 6.24 (3H, s, H7), 7.18-7.29 (12H, m, ArH), 7.89 (3H, bs, CONH), 11.21 (3H, bs, $\mathrm{NH}) .{ }^{13} \mathrm{C}$ NMR $\left(75 \mathrm{MHz}, \mathrm{CDCl}_{3}\right) \delta 37.4\left(\mathrm{CH}_{2}\right), 53.5\left(\mathrm{CH}_{2}\right)$, 54.8, $55.3(\mathrm{OMe}), 85.7(\mathrm{C} 5)$, 93.6 (C7), 126.8, 132.0 (ArCH), 113.1, 126.7, 129.2, 132.7, 132.9, 139.6, 156.5, 161.8 (ArC), 164.0, 173.2 (CO). MS (EI) m/z: 1171 (M, 2\%), 812 (2), 359 (22), 316 (24), 288 (100).

Tris-2-((3-(4-chlorophenyl)-4,6-dimethoxyindol-2-yl)-2-hydroxyethanamido-ethyl) amine (14). This was prepared as described for indole 13 from indole 12 (0.25 g, $0.21 \mathrm{mmol})$ to yield the title compound $14(0.22 \mathrm{~g}, 89 \%)$ as a white solid, mp $180^{\circ} \mathrm{C}$ (dec). Anal. Calcd. $\mathrm{C}_{60} \mathrm{H}_{60} \mathrm{Cl}_{3} \mathrm{~N}_{7} \mathrm{O}_{12}$. 0.6 H $\mathrm{H}_{2} \mathrm{O}$ : C, 60.6; H, 5.2; N, 8.3. Found: C, 60.3; H, 5.1; N, 8.0. IR $\left(\mathrm{KBr} \mathrm{cm}^{-1}\right)$ 3383, 1626, 1588, 1514, 1200, 1150, 1046. UV (MeOH nm, $\left.\left(\mathrm{cm}^{-1} \mathrm{M}^{-1}\right)\right) 202(75,600), 222$ (68,700), 270 (32,800). ${ }^{1} \mathrm{H}$ NMR (300 MHz, d 6 -DMSO) $\delta 2.64$ (6H, bs, $\mathrm{NCH}_{2}$ ), 3.24 (6H, bs, $\mathrm{NHCH}_{2}$ ), 3.63-3.69 (18H, m, OMe), 4.94 (3H, bs, CH), 6.15 (3H, s, H5), 6.30 (3H, bs, OH), 6.49 (3H, bs, H7), 7.34 (6H, m, ArH), 7.57 (6H, m, ArH), 7.92 (3H, bs, CONH), 10.89 (3H, bs, NH). ${ }^{13} \mathrm{C}$ NMR (75 MHz, d 6 -DMSO) $\delta 37.3\left(\mathrm{CH}_{2}\right), 53.3\left(\mathrm{CH}_{2}\right)$, 55.3, $55.5(\mathrm{OMe}), 66.5(\mathrm{CH}), 87.6$ (C5), 92.0 (C7), 127.2, 132.9 (ArCH), 110.5, 114.0, 130.7, 132.6, 134.5, 137.6, 154.4, 157.2 (ArC), 171.5 (CO). MS (ES) m/z: 1177 (M, $\left.{ }^{35} \mathrm{Cl}, 100 \%\right)$.

1-[3-(4-Chlorophenyl)-4,6-dimethoxyindole-7-yl]-2-phenylethanone (16a). The mixture of indole 8 (0.50 g, $1.74 \mathrm{mmol})$ and benzyl cyanide 15a $(0.55 \mathrm{~mL}, 4.76 \mathrm{mmol})$ in tetrahydrofuran $(10 \mathrm{~mL})$ was saturated with $\mathrm{HCl}$ gas for $1 \mathrm{~h}$ and stored in the fridge overnight. Flushing with $\mathrm{HCl}$ gas and keeping in the fridge was repeated on the next day. Then the solvent was evaporated off, the residue acidified with $2 \%$ aqueous $\mathrm{HCl}(40 \mathrm{~mL})$ and the resulting mixture refluxed for $3 \mathrm{~h}$. After cooling, diethylether was added and the precipitate was filtered off. The filtrate was washed with water until neutral, dried and concentrated. The residue was chromatographed with dichloromethane/methanol (95:5) to give the title compound 16a ( $0.32 \mathrm{~g}, 43 \%)$ as a yellow solid, mp 184- $186^{\circ} \mathrm{C}$. Anal. Calcd. $\mathrm{C}_{24} \mathrm{H}_{20} \mathrm{ClNO}_{3}$ : C, 71.0; H, 4.9; N, 3.4. Found: C, 70.9; H, 5.0; N, 3.4. IR ( $\left.\mathrm{KBr} \mathrm{cm}^{-1}\right)$ 3381, 1615, 1588, 1536, 1216, 1090, 938. UV (MeOH nm, $\left.\left(\mathrm{cm}^{-1} \mathrm{M}^{-1}\right)\right) 204$ (37,950), 251 (21,500), 331 (12,100). ${ }^{1} \mathrm{H}$ NMR (300 MHz, $\mathrm{CDCl}_{3}$ ) $\delta 3.91,4.01$ (6H, 2s, OMe), 4.42 (2H, s, $\mathrm{CH}_{2}$ ), 6.24 (1H, s, H5), 7.05 (1H, d, $\left.J=2.3 \mathrm{~Hz}, \mathrm{H} 2\right), 7.27-7.50$ (9H, m, ArH), 11.09 $\left(1 \mathrm{H}\right.$, bs, NH). ${ }^{13} \mathrm{C}$ NMR (75 MHz, $\left.\mathrm{CDCl}_{3}\right) \delta 50.8\left(\mathrm{CH}_{2}\right)$, 55.2, 56.1 (OMe), 87.2 (C5), 121.7 (C2), 126.3, 127.6, 128.2, 129.6, 130.6 (ArCH), 104.3, 110.2, 117.2, 131.6, 134.1, 136.3, 139.2, 159.6, 160.8 (ArC), 198.2 (CO). MS (EI) m/z: 409 (M+1, $\left.{ }^{37} \mathrm{Cl}, 32 \%\right), 407$ (M+1, $\left.{ }^{35} \mathrm{Cl}, 100\right), 289$ (3).

1-[3-(4-Chlorophenyl)-4,6-dimethoxyindole-7-yl]-2-[4-hydroxyphenyl]ethanone (16b). This was prepared as described for the indole 16a from indole 8 (0.50 g, $1.74 \mathrm{mmol})$ and 4- 
hydroxybenzyl cyanide $15 \mathrm{~b}(0.58 \mathrm{~g}, 4.35 \mathrm{mmol})$ in tetrahydrofuran $(10 \mathrm{~mL})$ to give the title compound 16b (0.26 g, 36\%) as an off white solid, mp $186^{\circ} \mathrm{C}$ (dec). Anal. Calcd. $\mathrm{C}_{24} \mathrm{H}_{20} \mathrm{ClNO}_{4}$ $0.4 \mathrm{H}_{2} \mathrm{O}$ : C, 67.2; H, 4.9; N, 3.2. Found: C, 67.1; H, 5.1; N, 2.9. IR $\left(\mathrm{KBr} \mathrm{cm}^{-1}\right)$ 3403, 1608, 1575 , 1346, 1214, 1172, 1091, 980. UV ( $\left.\mathrm{MeOH} \mathrm{nm},\left(\mathrm{cm}^{-1} \mathrm{M}^{-1}\right)\right) 202$ (42,750), 224 (28,000), 250 (21,850), 330 (12,100). ${ }^{1} \mathrm{H}$ NMR (300 MHz, $\left.\mathrm{CDCl}_{3}\right) \delta 3.91,4.01$ (6H, 2s, OMe), $4.34(2 \mathrm{H}, \mathrm{s}$, $\left.\mathrm{CH}_{2}\right), 4.89(1 \mathrm{H}, \mathrm{bs}, \mathrm{OH}), 6.24(1 \mathrm{H}, \mathrm{s}, \mathrm{H} 5), 6.78(2 \mathrm{H}, \mathrm{d}, J=8.3 \mathrm{~Hz}, \mathrm{ArH}), 7.05(1 \mathrm{H}, \mathrm{d}, J=2.3$ $\mathrm{Hz}, \mathrm{H} 2)$, 7.09-7.49 (6H, m, ArH), $11.05(1 \mathrm{H}, \mathrm{bs}, \mathrm{NH}) .{ }^{13} \mathrm{C}$ NMR $\left(75 \mathrm{MHz}, \mathrm{CDCl}_{3}\right) \delta 49.8\left(\mathrm{CH}_{2}\right)$, 55.2, 56.1 (OMe), 87.3 (C5), 121.7 (C2), 115.2, 127.6, 130.6, 130.7 (ArCH), 104.3, 110.3, 117.2, 128.3, 134.1, 139.3, 154.1, 159.6, 160.8 (ArC), 198.7 (CO). MS (EI) m/z: 424 (M, ${ }^{37} \mathrm{Cl}, 36 \%$ ), $422\left(\mathrm{M},{ }^{35} \mathrm{Cl}, 100\right), 304$ (13), 288 (13).

1-[3-(4-Chlorophenyl)-4,6-dimethoxyindole-7-yl]-2-[4-methoxyphenyl]ethanone (16c). This was prepared as described for the indole 16a from indole $8(0.50 \mathrm{~g}, 1.74 \mathrm{mmol})$ and 4 methoxybenzyl cyanide $15 \mathrm{c}(0.55 \mathrm{~mL}, 4.05 \mathrm{mmol})$ in tetrahydrofuran $(10 \mathrm{~mL})$ to give the title compound $130(0.11 \mathrm{~g}, 15 \%)$ as a white solid, mp $174-176^{\circ} \mathrm{C}$. Anal. Calcd. $\mathrm{C}_{25} \mathrm{H}_{22} \mathrm{ClNO}_{4} .0 .2$ $\mathrm{H}_{2} \mathrm{O}$ : C, 68.3; H, 5.1; N, 3.2. Found: C, 68.2; H, 5.2; N, 3.2. IR $\left(\mathrm{KBr} \mathrm{cm}^{-1}\right) 3418,1618,1581$, 1513, 1449, 1333, 1246, 1207, 1172, 1079. UV (MeOH nm, $\left.\left(\mathrm{cm}^{-1} \mathrm{M}^{-1}\right)\right) 203$ (43,600), 225 (30,750), 251 (24,250), 329 (13,200). ${ }^{1} \mathrm{H}$ NMR (300 MHz, $\left.\mathrm{CDCl}_{3}\right) \delta 3.79,3.91,4.02(9 \mathrm{H}, 3 \mathrm{~s}$, OMe), 4.35 (2H, s, $\left.\mathrm{CH}_{2}\right), 6.25$ (1H, s, H5), $6.88(2 \mathrm{H}, \mathrm{d}, J=8.6 \mathrm{~Hz}, \mathrm{ArH}), 7.05$ (1H, d, $J=2.6$ $\mathrm{Hz}, \mathrm{H} 2), 7.16-7.49(6 \mathrm{H}, \mathrm{m}, \mathrm{ArH}), 11.06(1 \mathrm{H}, \mathrm{bS}, \mathrm{NH}) .{ }^{13} \mathrm{C}$ NMR $\left(75 \mathrm{MHz}, \mathrm{CDCl}_{3}\right) \delta 49.8$ $\left(\mathrm{CH}_{2}\right)$, 55.2, 56.1 (OMe), 87.3 (C5), 121.7 (C2), 113.7, 127.6, 130.5, 130.6 (ArCH), 104.3, 117.2, 128.3, 131.6, 134.2, 158.1, 159.5, 160.7 (ArC), 198.6 (CO). MS (EI) m/z: 439 (M+1, ${ }^{37} \mathrm{Cl}$, 38\%), $437\left(\mathrm{M}+1,{ }^{35} \mathrm{Cl}, 100\right)$.

1-[3-(4-Chlorophenyl)-4,6-dimethoxyindole-7-yl]-2-phenylethanol (17a). This was prepared as described for hydroxy indole 13 from indole 16a (50 $\mathrm{mg}, 0.12 \mathrm{mmol}$ ) and excess sodium borohydride in methanol $(10 \mathrm{~mL})$ under reflux for $30 \mathrm{~min}$ to yield the title compound 17a (47 mg, 94\%) as a white solid, mp $176-178^{\circ} \mathrm{C}$. Anal. Calcd. $\mathrm{C}_{24} \mathrm{H}_{22} \mathrm{ClNO}_{3}: \mathrm{C}, 70.7 ; \mathrm{H}, 5.4 ; \mathrm{N}, 3.4$. Found: C, 70.4; H, 5.4; N, 3.5. IR ( $\left.\mathrm{KBr} \mathrm{cm}^{-1}\right)$ 3357, 1619, 1596, 1332, 1213, 1090. UV (MeOH $\left.\mathrm{nm},\left(\mathrm{cm}^{-1} \mathrm{M}^{-1}\right)\right) 203$ (42,100), 226 (35,050), 285 (14,550). ${ }^{1} \mathrm{H}$ NMR (300 MHz, $\mathrm{d}_{6}$-DMSO) $\delta$ 2.86-3.10 (2H, m, $\left.\mathrm{CH}_{2}\right), 3.68,3.75$ (6H, 2s, OMe), 5.34 (2H, bs, $\left.\mathrm{CH}, \mathrm{OH}\right), 6.33(1 \mathrm{H}, \mathrm{s}, \mathrm{H} 5)$, 7.16-7.53 (10H, m, ArH, H2), $10.58(1 \mathrm{H}, \mathrm{s}, \mathrm{NH}) .{ }^{13} \mathrm{C}$ NMR (75 MHz, d $\left.\mathrm{d}_{6}-\mathrm{DMSO}\right) \delta 43.6\left(\mathrm{CH}_{2}\right)$, 55.4, 57.3 (OMe), 68.2 (CH), 89.7 (C5), 123.3 (C2), 126.1, 127.7, 128.1, 129.7, 130.9 (ArCH), 109.4, 110.8, 115.2, 129.9, 135.8, 136.6, 140.1, 151.9, 153.1 (ArC). MS (EI) m/z: 409 (M+1, $\left.{ }^{35} \mathrm{Cl}, 14 \%\right), 392$ (40), 391 (100), 317 (14), 289 (7).

1-[3-(4-Chlorophenyl)-4,6-dimethoxyindole-7-yl]-2-[4-hydroxyphenyl]ethanol (17b). This was prepared as described for hydroxy indole 13 from indole $16 \mathbf{b}(50 \mathrm{mg}, 0.12 \mathrm{mmol}$ ) to give the title compound 17b (39 mg, $77 \%$ ) as a white solid, mp $157-158^{\circ} \mathrm{C}$. Anal. Calcd. $\mathrm{C}_{24} \mathrm{H}_{22} \mathrm{ClNO}_{4} .0 .5 \mathrm{H}_{2} \mathrm{O}$ : C, 66.6; H, 5.3 ; N, 3.2. Found: C, 66.7; H, 5.1; N, 3.4. IR ( $\left.\mathrm{KBr} \mathrm{cm}^{-1}\right)$ 3434, 1617, 1596, 1514, 1463, 1332, 1214, 1091. ${ }^{1} \mathrm{H}$ NMR (300 MHz, $\mathrm{d}_{6}$-DMSO) $\delta$ 2.78-2.92 (2H, m, $\mathrm{CH}_{2}$ ), 3.69, 3.75 (6H, 2s, OMe), 5.24 (2H, m, CH, OH), 6.31 (1H, s, H5), 6.61, 6.94 (4H, 2d, $J=8.3 \mathrm{~Hz}, \mathrm{ArH}), 7.15(1 \mathrm{H}, \mathrm{d}, J=2.3 \mathrm{~Hz}, \mathrm{H} 2), 7.33,7.52(4 \mathrm{H}, 2 \mathrm{~d}, J=8.6 \mathrm{~Hz}, \mathrm{ArH})$, 
9.01 (1H, s, OH). 10.55 (1H, s, NH). ${ }^{13} \mathrm{C}$ NMR (75 MHz, d 6 -DMSO) $\delta 42.7\left(\mathrm{CH}_{2}\right), 55.4,57.4$ (OMe), 68.5 (CH), 89.8 (C5), 123.3 (C2) 114.9, 127.7, 130.5, 130.8 (ArCH), 109.6, 110.8, 115.2, 129.9, 130.2, 135.8, 136.6, 151.9, 152.9, 155.7 (ArC). MS (EI) m/z: $425\left(\mathrm{M}+1,{ }^{35} \mathrm{Cl}\right.$, 10\%), 407 (100), 317 (14), 289 (7).

1-[3-(4-Chlorophenyl)-4,6-dimethoxyindole-7-yl]-2-[4-methoxyphenyl]ethanol (17c). This was prepared as described for hydroxy indole 13 from indole $16 \mathrm{c}(50 \mathrm{mg}, 0.11 \mathrm{mmol})$ to give the title compound $17 \mathrm{c}$ (43 mg, 86\%) as a white solid, mp $166-167^{\circ} \mathrm{C}$. Anal. Calcd. $\mathrm{C}_{25} \mathrm{H}_{24} \mathrm{ClNO}_{4} 0.4$ $\mathrm{H}_{2} \mathrm{O}$ : C, 67.4; H, 5.6; N, 3.1. Found: C, 67.4; H, 5.6; N, 3.2. IR ( $\left.\mathrm{KBr} \mathrm{cm}^{-1}\right)$ 3439, 1613, 1595 , 1512, 1462, 1332, 1248, 1090. ${ }^{1} \mathrm{H}$ NMR (300 MHz, d6-DMSO) $\delta$ 2.71-3.03 (2H, m, $\mathrm{CH}_{2}$ ), 3.69, 3.75 (6H, 2s, OMe), 5.29 (2H, m, CH, OH), 6.34 (1H, s, H5), 6.79, 7.08 (4H, 2d, $J=8.6 \mathrm{~Hz}$, ArH), 7.15 (1H, d, $J=2.6$ Hz, H2), 7.34, 7.52 (4H, 2d, $J=8.7$ Hz, ArH), 10.55 (1H, s, NH). A satisfactory ${ }^{13} \mathrm{C}$ NMR spectrum could not be obtained because of limited sample and solubility.

\section{Acknowledgements}

Financial support from the Australian Research Council is gratefully acknowledged. TDW also acknowledges receipt of an Indonesian Government Quality of Undergraduate Education (QUE) Scholarship.

\section{References and Notes}

1. Black, D. StC.; Craig, D. C.; Kumar, N. J. Chem. Soc., Chem. Commun. 1989, 435.

2. Black, D. StC.; Bowyer, M. C.; Kumar, N.; Mitchell, P. S. R. J. Chem. Soc., Chem. Commun. 1993, 819.

3. Black, D. StC.; Craig, D. C.; Kumar, N. Aust. J. Chem. 1996, 49, 311.

4. Black, D. StC.; Craig, D. C.; Kumar, N. Tetrahedron Lett. 1995, 36, 8075.

5. Black, D. StC.; Kumar, N.; McConnell, D. B. Tetrahedron 2000, 56, 8513.

6. Böhmer, V.; Goldmann, H.; Vogt, W. J. Chem. Soc., Chem. Commun. 1985, 667.

7. Paulus, E.; Böhmer, V.; Goldmann, H.; Vogt, W. J. Chem. Soc., Perkin Trans 2. 1987, 1609.

8. Böhmer, V.; Goldmann, H.; Kaptein, R.; Zetta, L. J. Chem. Soc., Chem. Commun. 1987, 1358.

9. Goldmann, H.; Vogt, W.; Paulus, E.; Böhmer, V. J. Am. Chem. Soc. 1988, 110, 6811.

10. Helgeson, R. C.; Mazaleyrat, J.-P.; Cram, D. J. J. Am. Chem. Soc. 1981, 103, 3929.

11. Cram, D. J.; Karbach, S.; Kim, H.-E.; Knobler, C. B.; Maverick, E. F.; Erickson, J. L.; Helgeson, R. C. J. Am. Chem. Soc. 1988, 110, 2229.

12. Black, D. StC.; Kumar, N.; McConnell, D. B. Tetrahedron 1996, 52, 8925. 